\title{
EDITORIAL
}

\section{Tax Havens Within the EU: Barriers, Harmonization, or Competition?}

\author{
Helmut Becker, Deloitte \& Touche, Düsseldorf
}

Irish 'Dublin Dock Companies', Belgian headquarters, and the scheduled reserves in the Netherlands for financing activities are catchwords for a development which some countries describe as 'tax dumping'. The German reaction to this development is remarkable.

In 1964, Germany published the so-called Tax Haven Report. As a consequence, the International Tax Act provided barriers against the emigration of persons, enterprises, and capital, thereby initiating the European CFC legislation, and after which the loopholes which arose were closed by additional legislation. However, recent events demonstrated that it is still possible to escape high German taxation.

Now a change in the underlying philosophy seems to have arisen. The German Government has recently published a new report on tax havens within the EU which was delivered to the parliamentary fiscal committee. In that report the German Government stated that its instruments against profit shifting and export of economic sources are no longer operative, and it does not see any further possibility of increasing the barriers. This change demonstrates that only two possibilities exist: either we harmonize taxes between EU Member States, or the competition enforces a State to adapt to the economic environment.

A tax harmonization would result in a relatively equal situation in the EU Member States. Remaining differences could be equalized by an allocation of revenues. After such harmonization, tax competition or even tax dumping would no longer make any sense.

If harmonization cannot be achieved, or it will take too long to achieve, the competition option has to be accepted, which means that the competing States have to establish the same advantages as their neighbours, or they have to create a tax level which makes tax advantages unnecessary, because otherwise the State not accepting the competition will lose out. Complaints about tax dumping may provide a moral platform, but the consequences of lost competition are not avoided.

Barriers against the export of persons, enterprises, and capital also do not help: history has proved this with the examples of the Roman Limes and the Great Wall of China or the Berlin Wall. If the pressure becomes too high, barriers will break. It seems that the German Government has learned that lesson. As tax harmonization is not to be seen on the European horizon, s. $8 \mathrm{~b}$ Corporate Income Tax Act has very much improved the tax situation for holding companies, and the tax reform already announced will decrease the German tax level, which are the right steps to win the competition.

If tax harmonization is undesirable or impossible, each State has to take care not to lose the competition. While complaints about tax dumping may have a realistic background, they do not provide any support for the economy. 